\title{
FUNGI COLONIZING SHOOTS OF COMMON YEW (TAXUS BACCATA L.) IN THE JAGIELLONIAN UNIVERSITY BOTANIC GARDEN IN CRACOW
}

\author{
Waldemar Mirski \\ Department of Plant Protection, Agricultural University of Cracow, Al. 29-Listopada 54, 31-425 Kraków, Poland \\ e-mail: wmirski@interia.pl
}

Received: 1.10 .2007

\section{S u m m a r y}

The aim of the investigations was determination the reasons of dying down of needles and branches of common yew (Taxus baccata L.) in the park collection of Botanic Garden of Jagiellonian University in Cracow. The disease changes of infectious nature were observed on the examined plants' parts. The changes'appearance, its location and extent were described in details. At first the spots were brown colour with distinct hem. Then the needle and branch tissues were dying down. From end of May to July mass falling down of infesteted needles was observed. Mycological analysis of diseased tissues showed 34 fungi species. To the dominant species belonged: Alternaria alternata, Colletotrichum gloeosporioides, Fusarium spp., Pestalotiopsis guepinii, Phomopsis juniperivora and Zythiostroma pinastri. Common yew pathogens: Phomopsis juniperivora and Sclerophoma pityophila were found among the isolated fungi.

Key words: common yew, Taxus baccata, needles, branches, fungi, disease symptoms

\section{INTRODUCTION}

Man has long planted gardens in which, inter alia, different trees and shrub species are found. In urbanised areas parks, among others, are such gardens. This greenery performs a comprehensive role as the aesthetic or environment-forming factor. They are also attributed with an advantageous effect on climatic conditions, dust retention, absorption of noxious gases, enrichment of air with oxygen, etc. ( $\mathrm{k} \mathrm{u} \mathrm{k} \mathrm{a} \mathrm{s} \mathrm{i} \mathrm{e} \mathrm{w} \mathrm{i} \mathrm{c} \mathrm{z,} \mathrm{1989).} \mathrm{One} \mathrm{of} \mathrm{our}$ native conifer species, recommended for use in urban plantings, is common yew (Taxus baccata L.), due to its resistance to adverse conditions existing in the urban environment ( $\mathrm{kukas}$ i ew i c z, 1989). This is a species which has been long appreciated, but relatively rarely found in urban plantings (Grzywacz, 2001). These plants, growing in urban green areas for many years, are subjected to the effect of different adverse abiotic factors. Hence, they become more susceptible to infec- tion by pathogens. There are a small number of studies on infectious diseases of yew, including fungal diseases (S i w e c k i, 1975). In phytopathological literature, the paper of Kapuścińs ki (1947) is one of the most frequently cited; the author mentions in it 21 fungi species occurring on yew needles and shoots. To date, the problem of healthiness of yew has been addressed in Poland mostly in the yew tree reserves in Wierzchlas and Rokita (Mańka et al. 1968, 1985; Mańka 1993). The authors identify the culprits of the dieback of yew seedlings - Cylindrocarpon radicicola (Mańk a et al. 1968) and C. destructans (M án k a 1993); as well as the culprits of yew wood rot, i.e. Phellinus hartigii and $P h$. pini ( $\mathrm{M}$ ań k a et al. 1985). But the problem of yew needle dieback is only addressed by $\mathrm{M}$ a ń $\mathrm{k}$ a (1992) who mentions the following fungi among the culprits of this disease: Macrophoma taxi, Phomopsis taxi and Coniothyrium fuckelii.

The aim of the study was to diagnose the causes of dieback of common yew needles and branches in the plantings of the Cracow Botanic Garden and to identify fungi species isolated from diseased tissues.

\section{MATERIALS AND METHODS}

The studies were conducted in the years 2005 2007 in the Jagiellonian University Botanical Garden in Cracow where the dieback of needles and branches of common yew (Taxus baccata L.) had been observed for over a dozen years. The investigated material comprised common yew individuals in the amount of 21 trees aged between 50 and 60 years. The studies covered one-, two- and three-year-old living needles with local infection spots as well as two- and three-year-old completely browned needles, still attached to the branch. Branches on which infection spots occurred and completely dead branches (1-, 2- and 3-year-old) were also subjected to the analysis. During the vegetation period, the most frequently occurring pathological changes (colour, 
shape, structure of infected tissues, presence of etiological symptoms) in the abovementioned organs were recorded and described. 10 pieces from each year group of needles were sampled from all the yew tree individuals. The same procedure was applied to the analysed branches. In the laboratory, 20 sections, 5-10 mm long, from each batch were excised separately in order to isolate fungi from tissues of the needles and branches affected by pathological symptoms or completely dead. These sections were rinsed in running water, subsequently they were surface disinfected in 75-percent ethanol for 1 minute and then rinsed again in sterile distilled water. After drying, the material was placed on potato dextrose agar medium (PDA) and incubated at a temperature of about $23^{\circ} \mathrm{C}$. The species in the grown colonies of fungi, after their separation and obtaining single spore cultures on the same growth medium, were identified using species identification keys and monographs (G a m s 1971; Domsch et al. 1980; Sutton, 1980; E11 is and E 11 is, 1985; K w a ś n a et al. 1991). The identification of fungi from the genus Penicillium was made based on the cultures grown on Czapek-Dox medium and malt medium ( $\mathrm{R}$ a $\mathrm{m}$ i r e $\mathrm{z}, 1982$ ). Isolates were made from a total of 200 needles and 160 branches sections. The results of fungi species identification were tabulated, taking into account the number of the obtained cultures and their percentage shares in the total population of the isolates. In addition, symptomatologic data were also tabulated, indicating symptom locations on needles and branches, as well as data documenting the colonization of diseased tissues by the isolated and identified fungi.

\section{RESULTS AND DISCUSSION}

The analysis of the healthiness of yew demonstrated the presence of infection spots both on 1-, 2 year-old and 3-year-old needles. The intensification of spot occurrence was different, depending on the age of the needles. On 1-year-old needles, spots occurred sporadically, whereas on 2-year-old needles their most frequent occurrence was found. In the case of 3-yearold needles, their complete browning and dieback were observed. The infection changes on the needles were initially observed as brown-coloured spots, and then as chocolate-coloured to dark brown spots, with a clear darker rim. They were first visible in the form of oval spots, expanding with time to the whole surface of the needles, in the final effect leading to their complete dieback. Similar pathological changes were also observed on the branches (2- and 3-year-old, sporadically on 1-year-old). These were dark brown necrotic streaks which were often located at the base of the needles. Subsequently, these streaks expanded along the branches as well as on their circumference, leading to their dieback together with the needles located above the place of spot occurrence. In the period from the end of May to July, the mass falling of dead needles was observed, mainly 3 -year-old needles, but also younger ones, which had died as a result of the death of the branch.

The mycological analysis showed the colonization of diseased common yew needles and branches by a complex of fungi.

From the diseased common yew tissues (needles and branches), 1085 cultures were obtained belonging to 34 species (Tab. 1, 2, 3). The following fungi occurred most frequently in the community of the fungi isolated from the investigated material: Phomopsis juniperivora, Alternaria alternata, Colletotrichum gloeosporioides and Zythiostroma pinastri.

Colletotrichum gloeosporioides and A. alternata were isolated most frequently from 1- and 2-year-old needles affected by the described pathological symptoms, whereas $P$. juniperivora and $S$. pityophila were isolated less frequently. Species such as Z. pinastri, P. juniperivora, A. alternata, Pestalotiopsis guepinii and C. gloeosporioides predominated in the isolates from the browned needles.

Phomopsis juniperivora, Z. pinastri and $C$. gloeosporioides were isolated most numerously from the branchs which showed spot disease and necrosis, whereas $P$. juniperivora, A. alternata and Fusarium spp. were isolated most frequently from dead branches.

In 2005, 323 fungi cultures belonging to 20 species were isolated (Tab. 1). Alternaria alternata, C. gloeosporioides, $P$. juniperivora and $Z$. pinastri were predominant among the obtained isolates. Fungi from the genus Fusarium - F. avenaceum and $F$. sacchari also occurred in great numbers, but the latter species was noted sporadically. Pestalotiopsis guepinii was also isolated frequently from dead tissues. In the population of the isolated fungi, saprotrophs, i.e. Chaetomium bostrychodes and sporadically Penicillium expansum, were also observed.

In 2006 a larger number of fungi colonies were obtained - 366 belonging to 19 species (Tab. 2). Similarly to the previous year, the same fungi species were predominant among them. In these isolates, fungi from the genus Fusarium (F. avenaceum, F. sacchari, F. sporotrichioides) occurred. More cultures of Pe. guepinii were isolated from dead yew needles compared to the previous year, likewise from living needles - the species $S$. pityophila. But another saprotrophic species was identified, i.e. Epicoccum purpurascens.

The largest number of fungi colonies was isolated in 2007, notably 396, among which 21 species were identified (Tab. 3). Just like in the previous years, the same fungi species predominated. But a smaller number of Pe. guepinii isolates was found, compared to the previous years, and in turn $S$. pityophila occurred only on living yew needles. In that year of study, the presence of 2 species from the genera Phoma - Ph. exigua and 


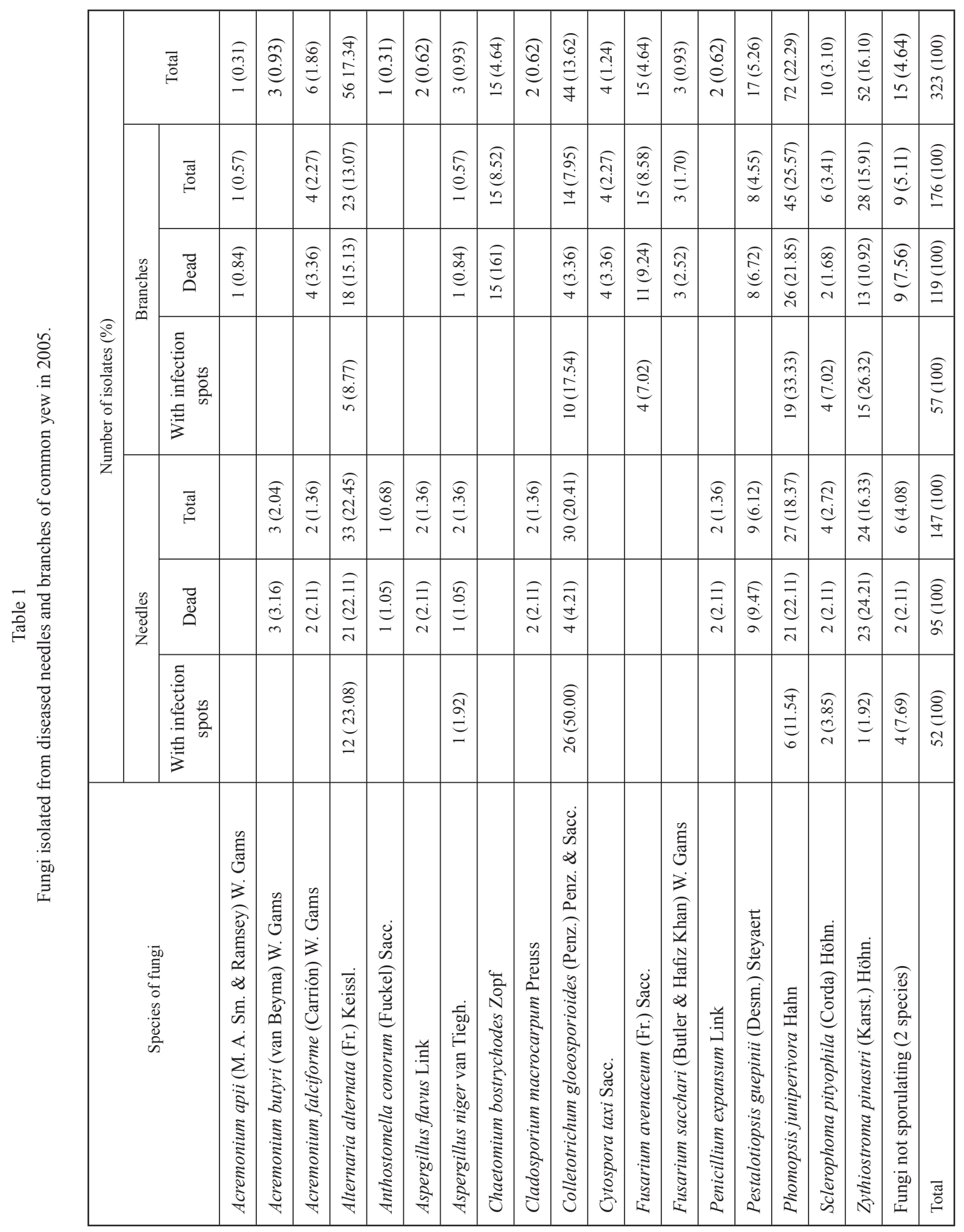




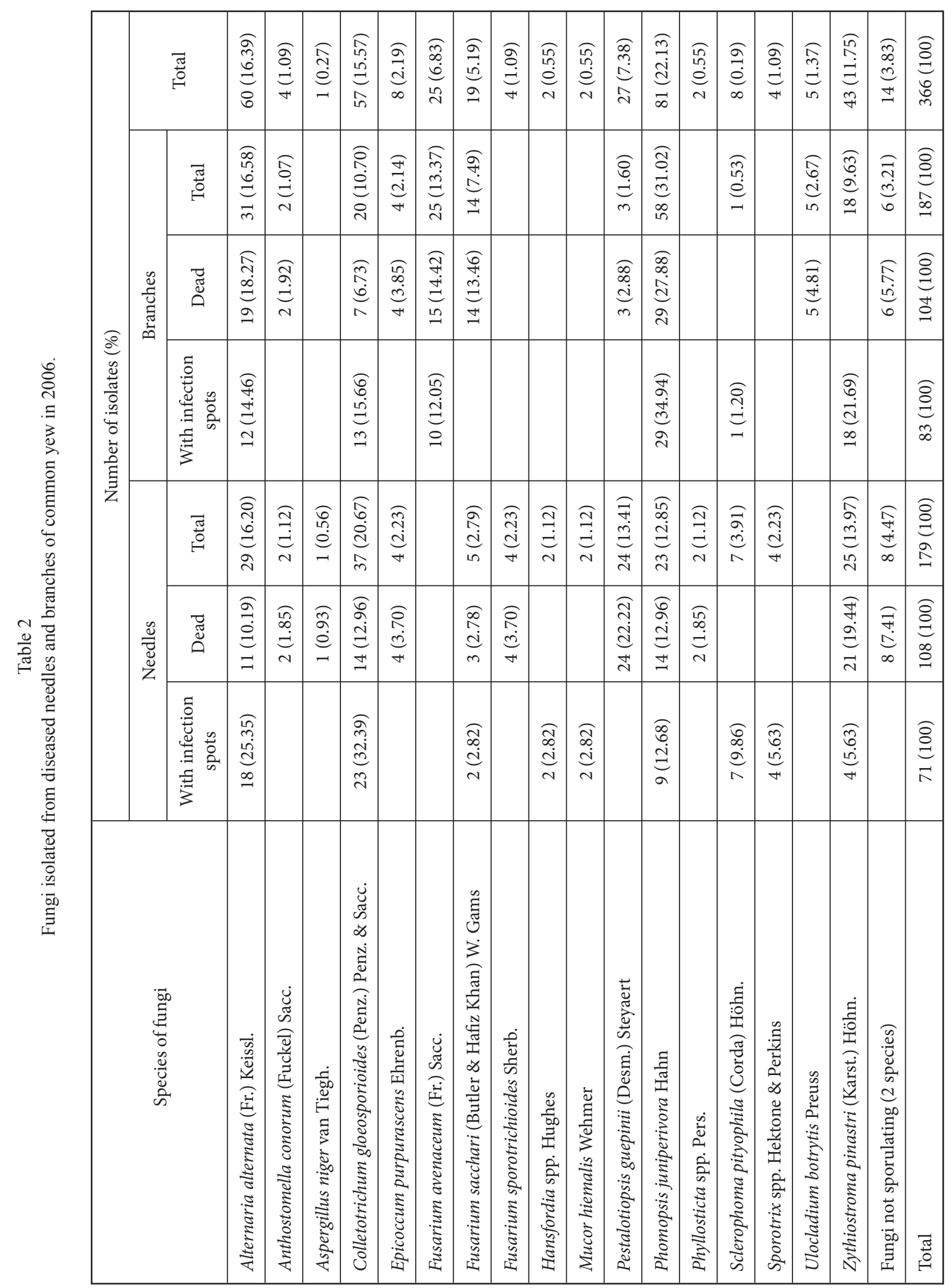




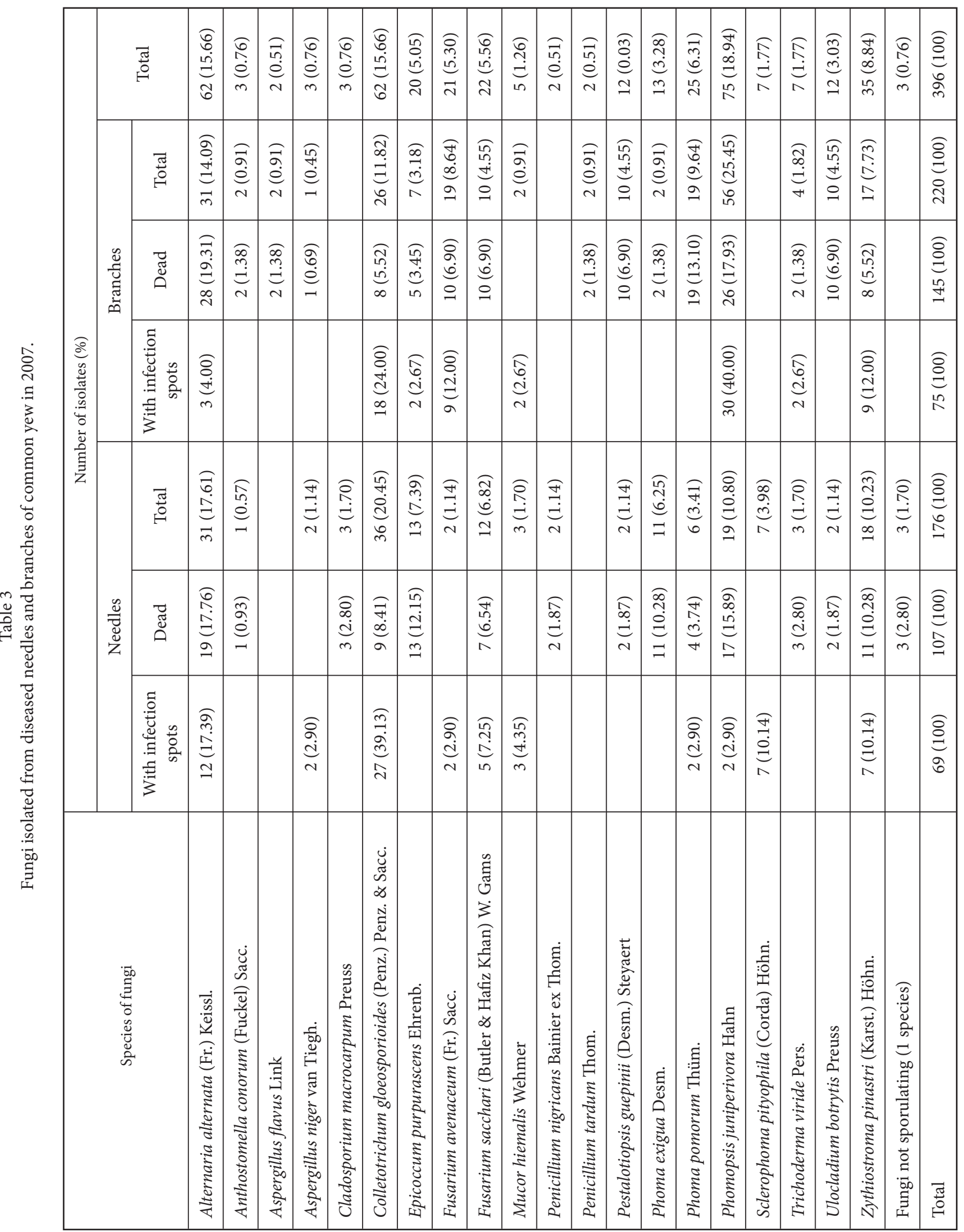


Ph. pomorum, was found for the first time which were isolated mainly from dead yew needles and branches. But saprotrophs, i.e. E. purpurascens as well as Penicillium nigricans, P. tardum and Trichoderma viride, were isolated more frequently than before.

The species Phomopsis juniperivora, which is recognised as a pathogen of this plant ( $\mathrm{S}$ i w e c k i, 1975; Grzywacz, 2001; Łabanowski et al. 2001), was isolated both from yew needles and branches. The obtained results confirm the presence of this fungus both in shoots and needles of common yew. This species is primarily the culprit of spot disease and the dieback of shoots (S i w e c k i, 1975; G r z y w a c z 2001), and its presence in diseased needles suggests that it may also be the culprit of their spot disease, and subsequently it may transfer from them to the branches ( $\mathrm{Eab}$ a n ow s k i et al. 2001).

In the studies, the presence of the fungus Sclerophoma pityophila was found, which is known as a pathogen of pine needles causing in them the disease called autumn needle cast (M án $\mathrm{k}$ a et al. 1979, 1982). In the studies of the present paper's author, this fungus was more frequently isolated from yew needles, which may indicate its participation in the development of pathological changes in them. G r z y w a c z (2001) mentions 11 other fungi species among the culprits of needle cast of yew, whereas $S$. pityophila is attributed only with the ability to infect young yew shoots.

The species Colletotrichum gloeosporioides was isolated most frequently from living needles affected by pathological changes. It may be the culprit of the described pathological changes on needles typical for anthracnose occurring on many plants. F u et al. (2003) reports the pathogenicity of this species for Taxus brevifolia and T. mairei seedlings in Taiwan.

From the tissues of common yew, the following fungi from the genus Fusarium were isolated: F. avenaceum, F. sacchari and F. sporotrichioides. They primarily develop as saprotrophs, which is consistent with the results obtained in these studies, since they occurred most frequently on dead tissues. Pathogenic forms, capable of causing infection in favourable conditions, may also occur among them. Werner and co-authors (2003) report the occurrence of $F$. oxysporum and its harmfulness to yew.

In the mycological analysis, the occurrence of the species Pestalotiopsis guepinii on dead needles and branches was also demonstrated. Many authors informed earlier about another species from the genus $P e s-$ talotiopsis, i.e. $P$. funerea, which is pathogenic for yew (K a p ús c ińs k i, 1947; S iw e c k i, 1975; Grzyw a c z, 2001; K o złow s k a et al. 2002). The presence of $P$. guepinii only in dead tissues may confirm the suggestions that it occurs as a saprotroph in the places of primary damage of needles or branches by other factors (Grzy w a c z, 2001).
In turn Zythiostroma pinastri, isolated quite frequently from shoots, may colonize them without causing any symptoms as an endophyte or participate in the production of pathological changes in them. As reported by S u t t o n (1980), this species has already been noted on yew shoots. Cytospora taxi was also isolated from dead branches; as reported by K a p u ś c i ń s k i (1947), it lives on debarked yew branches.

Alternaria alternata was frequently isolated both from living and dead organs affected by pathological changes. In accordance with Przyby 1 and $\mathrm{Bojar}-$ c z u k (1991), this species is recognised as a saprotroph of common yew. According to others, it is termed as the weakness pathogen of plants, since among many isolates there may be found those which show pathogenic abilities in relation to weakened plants on which they occur (K o packi and Wagner, 2005).

The appearance of certain pathogenic species among the isolated fungi may intensify, in particular under the influence of adverse atmospheric conditions, the presence of industrial emissions or the relevant age of tress, needles and branches (K ow a ls ki, 1987; Grzyw a c z, 2001).

The obtained results justify the expediency of the continuation of further studies on healthiness of common yew by determining the pathogenicity of identified fungi, and subsequently the possibility of protection against them.

\section{REFERENCES}

Domsch K. H., Gams W., Anderson T. H., 1980. Compendium of soil fungi. Academic Press, A Subsidiary of Harcourt Brace Jovanovich Publishers, London, New York, Toronto, Sydney, San Francisco, 859.

Ellis M. B., Ellis J. P., 1985. Microfungi on land plants. An identification Handbook. Macmillan Publishing Company, New York, 818.

Fu C. H., Hasiao W. W., Yao J. C., 2003. First report of anthracnose by Colletotrichum gloeosporioides on Taxus mairei in Taiwan. Plant Dis. 87 (7): 873.

Gams W., 1971. Cephalosporium-artige Schimmelpilze (Hyphomycetes). Gustav Fiscer Verlag, Stuttgart, 262.

Grzywacz A., 2001. Choroby cisa pospolitego. / Diseases of common yew. Sylwan, 145 (10): 5-21.

Kapuściński R., 1947. Cis jako roślina żywicielska. / Yew as a host plant. Wszechświat, 9: 267-272.

Kopacki M., Wagner A., 2005. Grzyby zasiedlające chore rośliny chryzantemy (Chrysanthemum x grandiflorum /Ramat./ Kitam) uprawianej pod osłonami w rejonie Sandomierza. / Fungi colonizing diseased plants of chrysanthemum (Chrysanthemum x grandiflorum /Ramat./ Kitam) grow under covers in Sandomierz region. Acta Agrobot. 59 (2): 213-224.

Kowalski T., 1987. Mikoflora chorych i zamarlych igieł Pinus sylvestris $\mathrm{w}$ drzewostanach Polski południowej. 
/ The mycoflora in the affected and dying needles of $P i$ nus sylvestris in south Poland. Zesz. Nauk. AR Kraków 17, Leśn. 212: 51-61.

Kozłowska M., Rybus-Zając M., Gniazdowska-Skoczek H., 2002. Reakcja metaboliczna Taxus baccata L. na porażenie grzybem Pestalotiopsis funerea Desm. w zależności od warunków siedliskowych. / Metabolic response of Taxus baccata L. to Pestalotiopsis funerea Desm. in dependence of environmental conditions. Acta Agrobot. 55 (1): 149-155.

Kwaśna H., Chełkowski J., Zajkowski P., 1991. Grzyby XXII. Fusarium. / Fungi XXII. Fusarium. Polska Akademia Nauk, Instytut Botaniki, Warszawa-Kraków, 137.

Łabanowski G., Orlikowski L., Soika G., Wojdyła A., 2001. Ochrona drzew i krzewów iglastych. / Protection of coniferous trees and shrubs. Plantpress, Kraków, 193.

Łukasiewicz A., 1989. Drzewa w środowisku miejsko-przemysłowym. / Trees in an urban-industral environment [In:] Życie drzew w środowisku skażonym. [ser.] Nasze drzewa leśne. T. 21, Warszawa, PWN: 49-85.

Mańka K., Gierczak M., Prusinkiewicz Z., 1968. Zamieranie siewek cisa (Taxus baccta L.) w Wierzchlasie na tle zespołów saprofitycznych grzybów środowiska glebowego. / The succumbing of yew - tree seedlings in Wierzchlas and the saprophytic fungi of the soil environment. Prace Kom. Nauk Roln. i Kom. Nauk Leśn. PTPN, 25: $177-195$

Mańka K., Przezbórski A., Chwaliński K., 1985. Zdrowotność cisów w rezerwacie „Cisy Staropolskie im. L. Wyczółkowskiego" w Nadleśnictwie Wierzchlas. / Diseased of Taxus baccata (L.) in the reserve of Wierzchlas. Folia Forestalia Polonica Seria A, 26: 101-112.

Mańka K., Przezbórski A., Szymanowicz I., 1979. Choroba igieł sosny pospolitej powodowana przez grzyba Sclerophoma pityophila (Corda) v. Höhn. Disease of Scot pine needles caused by the fungus Sclerophoma pityophila (Corda) v. Höhn. Sylwan, 123 (6): 23-31.

Mańka K., Przezbórski A., 1982. Dalsze obserwacje związane $\mathrm{z}$ występowaniem w Polsce choroby igieł powodowanej przez grzyb Sclerophoma pityophila (Corda) v. Höhn. / Further observations on the occurrence of pine needle disease caused by the fungus Sclerophoma pityophila (Corda) v. Höhn. in Poland. Sylwan, 126 (4): 1119.

Mańka M., 1992. Fungi inhabiting needles of diseased yew trees (Taxus baccata L.) in Rokita reservation (rezerwat „Cisy Rokickie”). Phytopathol. Pol. 4 (XVI): 49-54.

Mańka M., 1993. Communities of fungi from roots and rhizosphere of yew (Taxus baccata L.) seedlings and their effect on the pathogenic root fungus Cylindrocarpon destructans (Zinss) Scholten. Phytopathol. Pol. 5 (XVII): $51-58$.
Przybył K., Bojarczuk T., 1991. Wstępne badania nad zamieraniem igieł i gałęzi niektórych gatunków krzewów iglastych w Arboretum Kórnickim. / Preliminary studies on the dying of needles and branches of some conifer shrubs in Kórnik Arboretum. Arbor. Kórnickie, 36: $137-$ 145.

Ramirez C., 1982. Manual and atlas of the Penicillia. Elsevier Biomedical Press. Oxford, 876.

Siwecki R., 1975. Choroby i szkodniki cisa pospolitego. / Diseases and parasitic insect of the yew. [In:] Cis pospolity - Taxus baccata L. [ser.] Nasze drzewa leśne. T. 3, Warszawa-Poznań, PWN: 125-133.

Sutton B.C., 1980. The Coelomycetes Fungi Imperfecti with Pycnidia Acervuli and Stromata. Commonwealth Mycological Institute, Kew Surrey, England, 697.

Werner M., Frużyńska-Jóźwiak D., Andrzejak R., 2003. Szkodliwość grzybów z rodzaju Fusarium dla krzewów ozdobnych i drzew parkowych. / Harmfulness fungi of the genus Fusarium for ornamental bushes and park trees. Prog. Plant Protection/Post. Ochr. Roślin, 43 (2): 1022-1025.

\section{Grzyby zasiedlające pędy cisa pospolitego (Taxus baccata L.) w Ogrodzie Botanicznym UJ w Krakowie}

\section{Streszczenie}

Badania miały na celu określenie przyczyn zamierania igieł i gałązek cisa pospolitego (Taxus baccata L.) w kolekcji Ogrodu Botanicznego UJ w Krakowie. $\mathrm{Na}$ badanych cześsiach roślin występowały zmiany chorobowe o charakterze infekcyjnym. Opisywano szczegółowo ich wygląd, zlokalizowanie i zasięg. Początkowo były to plamy brazzowawo zabarwione $\mathrm{z}$ wyraźną obwódką. Następnie tkanki igieł i gałązek zamierały. Obserwowano też masowe opadanie porażonych igieł w okresie od końca maja do lipca. Przeprowadzona analiza mikologiczna chorych tkanek wykazała w nich obecność 34 gatunków grzybów, wśród których dominowały: Alternaria alternata, Colletotrichum gloeosporioides, Fusarium spp., Pestalotiopsis guepinii, Phomopsis juniperivora oraz Zythiostroma pinastri. W populacji wyizolowanych grzybów stwierdzono obecność patogenów cisa pospolitego, tj.: Phomopsis juniperivora i Sclerophoma pityophila. 


\title{
ACTA AGROBOTANICA Vol. 61 (1) 2008
}

\author{
AUTHOR INDEX
}

Bożena Denisow, Małgorzata Wrzesień, Anna Cwener: The estimation of Adonis vernalis populations in chosen patches of Lublin Upland

Elżbieta Weryszko-Chmielewska, Małgorzata Bożek: Structure of trichomatous nectaries in flowers of Lonicera kamtschatica (Sevast.) Pojark.

13

Agata Konarska: Changes in the ultrastructure of Capsicum annuиm L. seedlings roots under aluminum stress conditions

Krystyna Piotrowska: Ecological features of flowers and the amount of pollen released in Corylus avellana (L.) and Alnus glutinosa (L.) Gaertn.

Krystyna Piotrowska: Pollen production in selected species of anemophilous plants

Agnieszka Dąbrowska: The influence of weather conditions on the course of pollen seasons of alder (Alnus spp.), hazel (Corylus spp.) and birch (Betula spp.) in Lublin (2001-2006)

Katarzyna Ceglińska: Anemophilous plant pollen in spring specific honeys from the Rzeszów area

Jolanta Marciniuk, Anna Rudzińska-Langwald: Morphological diversity of pollen from selected species of the genus Taraxacum, according to their ploidal level 65

Ewa Szpadzik, Ewa Jadczuk-Tobjasz, Barbara Łotocka: Preliminary evaluation of pollen quality, fertility relations and fruit set of selected sour cherry cultivars in polish conditions

71

Elżbieta Kaczmarska, Agnieszka M. Dobrowolska, Jerzy A. Hortyński: The influence of pollen viability on seed set and fruit mass in strawberry (Fragaria $x$ ananassa Duch.)

Marcin Zych, Andrzej Jakubiec: Pollination of Polish red list plants: a preliminary statistical survey $\quad 85$

Magdalena Pogorzelec: The downy willow (Salix lapponum L.) population on the peat bog near Lake Bikcze (Łęczyńsko-Włodawskie Lakeland)

91

Marta Dmitruk: Flowering, nectar production and insects visits in two cultivars of Cucurbita maxima Duch. flowers 99

Agnieszka Sękara, Monika Bieniasz: Pollination, fertilization and fruit formation in eggplant (Solanum melongena $\mathrm{L}$.)

107

Marium Tariq, Shahnaz Dawar, Fatima Sultana Mehdi and Muhammad Javed Zaki: The effect of mangroves amendments to soil on root rot and root knot of potato (Solanum tuberosum L.) 115
Stanisław Wociór: The effect of rootstocks on the growth and yielding of sour cherry cv. 'Łutówka' 123

Ewa Krasicka-Korczyńska: Effect of the cutting date on blooming and fruit-bearing of Ostericum palustre Beesser

Anna Pobudkiewicz: The influence of growth retardants and cytokinins on flowering of ornamental plants 137

Jarosław Zieliński: The characterization of the blooming of woodbine Lonicera periclymenum $\mathrm{L}$.

143

Grzegorz Nowak, Jarosław Zieliński: Blooming of romanas rose (Rosa rugosa Thunb.) cultivated on ash dumps reclaimed with various techniques

149

Elżbieta Pogroszewska, Patrycja Sadkowska: The influence of benzyladenine on the flowering of Liatris spicata L. 'Alba' cultivated for cut flowers in an unheated plastic tunnel and in the field

153

Elżbieta Pogroszewska, Halina Laskowska: The influence of cultivation method on the flowering of Salvia horminum L. 'Oxford Blue'

159

Sylwia Andruszczak: The influence of the plantation establishment method on the yield of marshmallow (Althaea officinalis L.) flowers

Krystyna Pudelska: Evaluation of growing and flowering of FIVE species of ornamental grasses in the region of Lublin

Krzysztof Gęsiński: Evaluation of the development and yielding potential of Chenopodium quinoa Willd. under the climatic conditions of Europe

Part one: Accomodation of Chenopodium quinoa (Willd.) to different conditions

Krzysztof Gęsiński: Evaluation of the development and yielding potential of Chenopodium quinoa Willd. Under the climatic conditions of Europe

Part two: Yielding potential of Chenopodium quinoa under different conditions

Waldemar Mirski: Fungi colonizing shoots of common yew (Taxus baccata L.) in the Jagiellonian University Botanic Garden in Cracow

191 
